\title{
THE SYSTEM \\ OF DIVINE SERVICE QUOTATIONS IN THE LIFE OF STEPHEN OF PERM
}

Epiphanius the Wise, the Russian fifteenth-century hagiographer, is well-known as an unexcelled stylist. A monk of the Holy TrinitySt. Sergius Lavra, and one of the most learned and multi-talented people of his time, he was the author of at least two saints' Lives - Sergius of Radonezh and Stephen of Perm. Moreover, the authorship of $A$ Word on the Life and Repose of Demetrius Ivanovich, Tsar of Russia is most often ascribed to this same hagiographer. The unique style of his works has elicited and continues to elicit the interest of researchers. The analysis of the particularities of his work, in the opinion of L. A. Dmitriev, is "the critical, central problem in the study of the Russian hagiography linked with the second wave of South Slav influence." ${ }^{1}$

One of the most interesting particularities of Epiphanius' style was his broad use of various quotations, reminiscences and allusions in hagiographical prose. The Life of Stephen of Perm (LSP), to which our work is dedicated, is one of the most extended Slavonic lives written in the special, flowery style characteristic of the epoch of the second wave of South Slav influence. An important function in the creation of this style is carried out by quotation; it plays a style-forming role in the Life of Stephen of Perm.

In this text the author most often resorts to two literary sources: the Bible and the texts of the Divine services. The Gospel, and especially the epistles of the apostles, are, after the Psalter, quoted most often in the Life of Stephen of Perm. In 1995 G. M. Prokhorov published a text of the Life in which he did work on singling out the quotations from the Psalms and other parts of the Bible in Epiphanius' composition. ${ }^{2}$ Evidently, in resorting to such frequent quotation from the apostolic

(1) Л. А. Дмитриєв, Нерешенные вопросы происхождения и истории экспрессивно-эмоционадьного стиля XV в., ТОДРЯ 20 (1964) 72-89.

(2) Г. М. Прохоров (изд.), Святитель Стефан Пермский: к 600-летию со дня преставления (Санкт-Петербург, 1995). 
epistles, Epiphanius the Wise was underlining the likeness between Stephen and the apostles. This supposition is supported by the fact that the work contains several altered fragments from the Life of Cyril and Methodius, which implies that Epiphanius was making parallels between the apostles, the equal-to-the-apostles enlighteners of the Slavs and Stephen of Perm. The skilful and at times hardly noticeable interweaving of the text of the Gospel with the Life, together with the fragment from the Life of Cyril and Methodius, which was well-known to the medieval reader, forces the recipient involuntarily to see in the image of Stephen a new Russian apostle, equal to the ancient preachers.

The quotations from the Divine service texts, in which the Life of Stephen also abounds, have never received sufficient illumination in the research literature. Moreover, the frequency of their use in the Epiphanius' composition tells about a definite writer's intention on the part of the author.

In the text of the Life under review we can distinguish several cycles of quotations, each of them bound up with this or that theme. Thus the first of them is constituted by the already-mentioned quotations from the apostolic epistles and Lives of the Equal-to-the-Apostles. These quotations, in our opinion, have already been sufficiently studied. The second cycle is constituted by quotations from the heirmoses of the canons, which are brought together into an elegant system and represent one of the levels of the complex structure of the text of the Life. The source of the third cycle is the Triodion - a collection of Divine services for the Great Lent, Holy Week and Pascha.

Thus the chapter entitled "Prayer for the Church" is a mixture of various kinds of Divine service hymns - the heirmoses - which are constituent elements of the hymnographic canon. In the Life of Stephen the heirmoses of the canons are quoted - that is, those hymns which were well-known to the medieval reader from the Divine services (in contrast with the canon, it was supposed that the akathist would be read in the cell). Epiphanius often reworks the texts of the heirmoses, adapting them to his style, but the general character of the hymnographical work, its lexicon and symbolism, remain unchanged. The beginning of the chapter in question in Epiphanius looks as follows (the fragments similar to the heirmoses have been underlined and indicated with corresponding numbers):

«[...] Иже словом в начатц' үТтержий невеса, разумом(1) и невесного круга врьхъ створь (2), ИЖе наА водамн нево уттер-

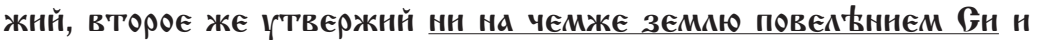


распространнв неОАръжНМџю земную ТяГОТУ, ЮЖЕ на ТВЕРАН Ея

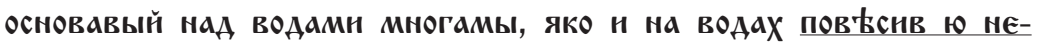
ОАръжнмо (3); съА ТТЕпная сүщн и съАръжащна вся Божня сниа

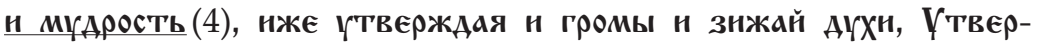
женне сый твердое, и недвнжныое Речеnне, и УТверженье на Тя надњющнмся(5), н Ты есн УТверженье прнтькающнм Ти,

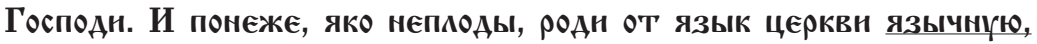
неплодящую церковь (6) Эвою утверАн, Хрнсте, юже стяжа сниою Креста Твоего [...], юже стяжа честною Ян кровню(5), юже у'ТверАн, Господн, на камени тверА ҚМъ, на каменн недвнжнм'М, на

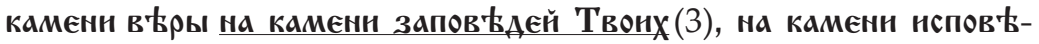
Аания Твоего, на камени церковнЊм».

"[...] Who hast in the beginning established the heavens by Thine understanding (1), and built the vault of heavens (2)..., Who hast established the heavens upon the waters, and again hast established the earth upon nothing by Thine ordinance and hast spread out the ungovernable weight of the earth, founding it firmly upon many waters, as Thou hast hung it ungovernably upon the waters (3); O Wisdom and Power of God, the Creator and Sustainer of all (4), Who hast established the thunders and the winds, being the firm Establishment and Immovable Word, and the firm Foundation of all that hope in Thee (5), and Thou art the Foundation of all that flee to Thee, O Lord. And do Thou establish, O Christ, the infertile Church of the Gentiles (6), which Thou hast acquired by the power of Thy Cross [...], which Thou hast acquired by Thine honourable blood (5), which do Thou establish, O Lord, on the firm rock, on the immovable rock, on the rock of faith, on the rock of Thy commandments $(1,3)$, on the rock of Thy confession, on the rock of the Church."3

Here we have a mixture of several heirmoses:

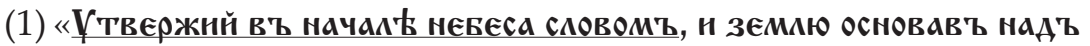
водамн многамн, гтверАн мя на пенне сиавословня Твоего, Господн» ("Having established the heavens in the beginning by Thine understanding, and founded the earth upon the waters, establish me, $\mathrm{O}$ Christ, on the rock of Thy commandments, for there is none holy as Thou, O only Lover of man"). ${ }^{4}$

(3) Прохоров, Святитель Стефан Пермский.., 236.

(4) Ирмолог 14 в. (РГБ, собр. Тр.-Серг. Лавры, ф. 304/I, № 19) 138 об.

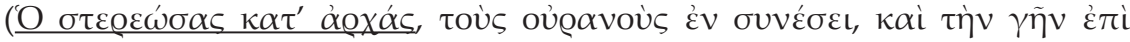

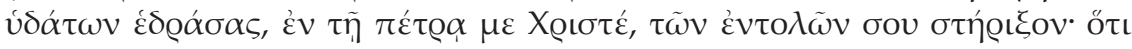

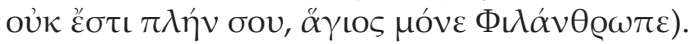


(2) «Невесному кругу верхотворче Господн, Церквн Знжнтелю, Ты ме үТверан в мювви Эвоей, желаньемь си Край, в Брнымъ үтверженье, еднне Человеколювче» (“O Lord, Builder of the vault of heaven, and Founder of the Church, do Thou establish me in Thy love, $\mathrm{O}$ summit of desires, $\mathrm{O}$ establishment of the faithful, O only Lover of man"). ${ }^{5}$

(3) «УТвержнй на ничесомьже земаю повеленнемъ Твонмъ ЯН, и распространи неОдержнмую тягоТҢ, на недвнжнмемь, ХрнстЕ, камени заповеднй Ти, Церковь Твою үтвердн, еднный Блаже и Человеколювче) ("By Thine ordinance has Thou set up the earth on nothing, and hung it while its weight ungovernably drags it down, do Thou establish Thy Church, O Christ, on the rock of Thy commandments, O only Good One and Lover of man"); ${ }^{\prime \prime}$

(4) «ОодЬТепьная и содержащая вся Божїя снио и мүарость, не-

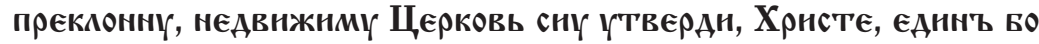
еси Өвят"ъ, и на святых"ъ почнваяй» (“O Wisdom and Power of God, the Creator and Sustainer of all, establish the Church, O Christ, unbending and immovable, for Thou only art holy, Who restest in the saints"). ${ }^{7}$

(5) «Утверженье на Тя надеющнмся, уТтержан, Господн, Церковь Өвою, юже стяжа честною Ян кровью" ("О firm Foundation of all that hope in Thee, do Thou establish, O Lord, the Church, which Thou hast acquired by Thine honourable blood" $).{ }^{8}$

(6) «Процвела есть пустыня, яко крннъ, Господн, язычна неплодящня Церковь, прншествием Ти, в нейже үтверднся моє сердцє» ("Like a lily, O Lord, has the infertile Church of the

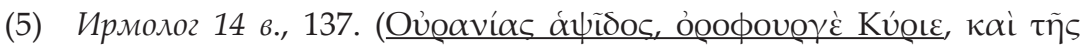

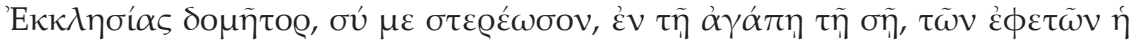

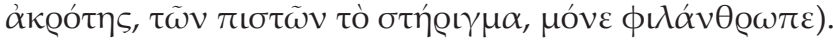

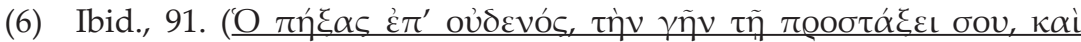

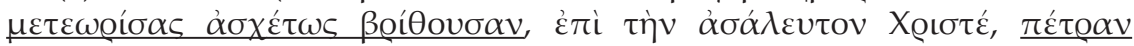

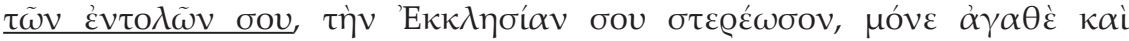

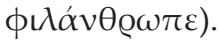

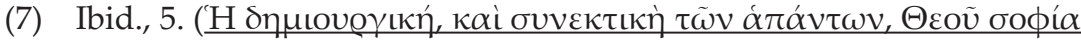

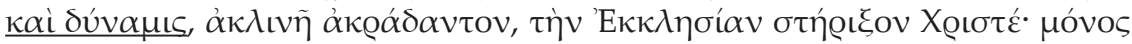

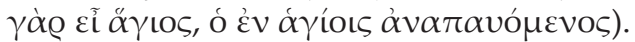

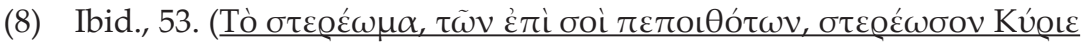

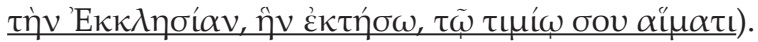


Gentiles flowered, by Thy coming, and my heart is established on her"). ${ }^{\prime}$

In several sentences Epiphanius the Wise has inserted fragments of six different heirmoses, interweaving them amongst themselves and putting in his own words. On the one hand, this is reminiscent of quotations from the Psalter, fragments of which are often found in Epiphanius interwoven and changed in accordance with his own style. V. A. Moshin explained this particularity of quoting from the Psalter in Epiphanius and the Serbian hagiographers by the fact that the authors knew the Psalter by heart and not only wrote, but also thought in its images and expressions. This, from V. A. Moshin's point of view, allowed the medieval hagiographers to quote from the Psalter involuntarily, without noticing it themselves. Moreover, the investigations of F. Wigzel have demonstrated that Epiphanius quoted Biblical texts in the form in which they are used in Divine services, which means that he is quoting them from memory, without going directly to the source..$^{10}$ It appears, by contrast, that when he is quoting the heirmoses and other Divine service texts, Epiphanius the Wise is deliberately looking up the source, or, at any rate, guessing the fragments that are appropriate in the given case with exceptional intuitiveness. The choice of quotations in the fragment quoted above strikes one with their appropriateness: first, the hagiographer chooses for "Prayer for the Church", not just any liturgical texts, but precisely the genre of the heirmos in its capacity as literary source; secondly, he resorts to strictly defined heirmoses. As is well-known, there are nine odes in all in the canon, each of which has an heirmos at the front. In creating the chapter in the Life of Stephen of Perm that we are studying, Epiphanius resorts to heirmoses of the third ode. In the general structure of the church service the heirmoses of the canons carry out the functions of idiosyncratic logical ties between a concrete church feast and Biblical history. In the heirmos, as a rule, there is mention of this or that critical event in Holy Scripture, while the corresponding ode of the canon is dedicated to the event being celebrated and usually has something in common with the heirmos preceding it, and so also with Biblical histo-

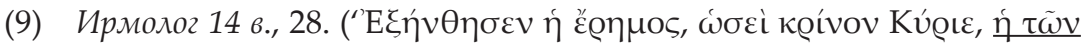

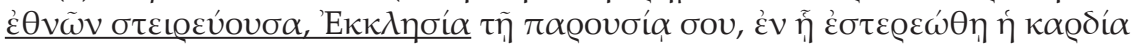
$\left.\mu \mathrm{Ov}^{\prime}\right)$.

(10) Ф. ВигзЕдл, Цитаты из книг Священного Писания в сочинениях Епифания Премудрого, ТОДРЯ 26 (1971) 232-243. 
ry. Thus the first heirmos is always dedicated to Israel passing though the Red sea, the second - to the wandering through the desert and the penitential song of Moses, while the third, to which Epiphanius resorts in the quoted fragment, has several meanings. First, the prayer of Anna, the mother of the Prophet Samuel, is remembered. Secondly, it speaks about love and asks for this heavenly gift: «Въ мювви Твоей үтверди мене» ("Establish me in Thy love"). Thirdly, the content of this heirmos is often linked with the act of creation: «УТверждєй в начал' невеса словомъ..." ("Having established the heavens at the beginning by Thine understanding..."). Fourthly, it usually includes a petition for the establishment of the heart on «каменн заповедей Твонх"ъ» ("the rock of Thy commandments"). And finally, fifthly, it praises God for bringing the Gentile tribes into the Church and asks for the establishment of the Church. All five meanings (perhaps the ancient heirmoses included various other meanings, but in the given case we limit ourselves to the five most obvious) are closely linked amongst themselves: the prayer of Anna was for the establishment that is necessary for every man, which serves as the foundation for the establishment of the whole Church. But the Church is established, not by men, but by the God Who created all things, so the petition for the Church is bound up with a reference to the creation of the world. The critical word and the critical petition of practically all the heirmoses of the third ode is "establishment". But this word becomes critical also in the "Prayer for the Church" of Epiphanius. Moreover, the author is constantly quoting only separate fragments of heirmoses, most often their initial phrases, as if not speaking openly about the petition itself, but only hinting at it. The medieval reader, who knew the service well, must willingly or unwillingly caught the parallel places in the texts of Epiphanius, and, remembering the heirmoses by heart, was forced as it were to say opely what the hagiographer did not say openly, that is, the petition for establishment which Epiphanius usually left out. Thus, for example, when reading in Epiphanius «Итверженне на Тя надеющимся» ("The Establishment of those who hope on Thee"), a person who knew the service must involuntarily have remembered the following phrase of this heirmos: "ГТтердн, Господн, Церковь» ("establish, O Lord, the Church"). In the course of the quite large fragment of text the hagiographer holds the reader in suspense and only at the end, twice in row, himself pronounces the word "Г'тверди» ("еstablish"): «Церковь Өвою үтвердн, Хрнсте, юже стяжа сниою Креста Твоего [...], юже стяжа честною Яи кровню, юже үТтерАн $[. .$. 
("Establish, O Christ, Thy Church, which Thou hast acquired by the power of Thy Cross (...), which Thou hast acquired by Thine honourable blood, which establish $(\ldots)^{\prime \prime}{ }^{11}$

We have analysed only the beginning of the "Prayer for the Church", but Epiphanius has interwoven quotations from the heirmoses of the third ode throughout this chapter, insistently repeating the word "establishment". In this chapter it becomes central.

In an analogous way, the whole text of the Life of Stephen of Perm is filled with quotations from the services of the Church. In the "Three Laments" which conclude the work, such fragments are found a little more than in the narrative itself, where, as a rule, Epiphanius resorts to reminiscences or liturgical texts. Within the bounds of this investigation the greatest interest is presented by the latter, which are linked with the author's prayerful mood. In the previous section, which was dedicated to the role of amplification in Epiphanius' hagiography, we examined two examples of Divine service quotations in the Life of Stephen. One of them, as we have seen, was taken by the author from the verses on the Sunday of the Expulsion of Adam. This Sunday precedes the beginning of the Great Fast in the Orthodox service cycle and enters into the so-called Triodion cycle, that is, into the cycle of services before the Great Fast, Pascha and the seven weeks after Pascha. In the Life of Stephen of Perm the majority of hymnographical quotations are bound up precisely with the Triodion cycle. Let us compare several fragments of the Life with the Divine service texts (similar points are underlined). In describing the conversation of Stephen of Perm with the wizard Pam, Epiphanius puts into the mouth of his hero the following words:

«То во есть Богъ вогов Господь господемъ, Царь царемъ, Єгоже Аержава непрем Бнна и слава непостнжима, нже жнветь в св БТЬ нензреченн', непрнстүпн' и непрнкосновенн', Емүже предстоят съ страхом и с трепЕтом неБесная вонньства, БеспмотныХЪ чннове; и тмы тМам архангеАъ преАстоят предъ Ннмъ, и тысяща тысящамн ангекъ смүжат Емү, нже Беспрестани славят, и вопнюще гА⿱голющеє [...]» ("For He is the God of gods, the Lord of lords, the King of kings. His sovereignty will not pass away and his glory is unattainable, He lives in ineffable light that is unapproachable and inviolable. Before Him stand with fear and trembling the heavenly hosts, the ranks of the bodiless ones; and multitudes of archangels stand before Him, and thousands upon thousands of

(11) Прохоров, Святитель Стефан Пермский..., 236. 
angels serve Him, ceaselessly glorifying Him and crying out and saying $[\ldots]) .^{12}$

This fragment is reminiscent of the central hymn from the liturgy of Great Saturday:

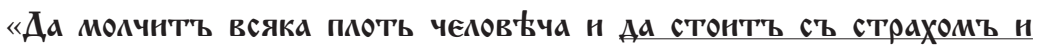

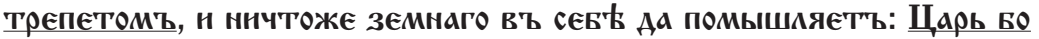

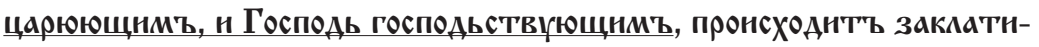

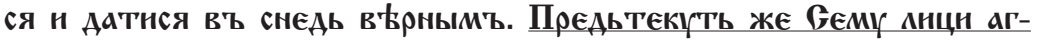
гельстнн со всемъ началы н властьмн, мноочнтая Херувнмъ н шестокрниатая Яерафнмъ, мнца закрывающе н вопнюще песнь [...]» ("Let all mortal flesh keep silence and stand with fear and trembling, and let it take no thought for any earthly thing: for the King of kings and Lord of lords draws near to be sacrificed and given as food for the faithful. Before Him go the choirs of angels and all the principalities and powers, the many-eyes cherubim and the six-winged seraphim, which cover their faces as they cry out this hymn $[\ldots]) .^{13}$

Let us continue Epiphanius' interrupted quotation, so as to reveal one more source: after the cited fragment the hagiographer passes smoothly over to a quotation from another liturgical text, that is, to the hymn that follows in the Divine service after what we have quoted and which is one of the main hymns in any Liturgy, insofar as it immediately touches upon the celebration of the Eucharist. Epiphanius writes: «[...] и вопнющє, гиаголющє: Явятъ, Явятъ, Явятъ Господь Gаваоф! Полно нево и земкя скавы Gго!» ("... and crying out and saying: Holy, Holy, Holy is the Lord of Sabaoth! Heaven and earth are full of His glory!"). Let us compare this with the liturgical hymn: «Gвят"ъ, свят" свят"Ъ Господь Gаваофъ, нсполнь нево и земкю славы Твоея [...]» ("Holy, Holy, Holy is the Lord of Sabaoth, heaven and earth are full of Thy glory $\left.[\ldots]^{\prime \prime}\right){ }^{14}$

(12) Прохоров, Святитель Стефан Пермский..., 132-134.

(13) Служебник XV в. (РГБ, собр. Тр.-Серг. Лавры, ф. 304/I, № 216),

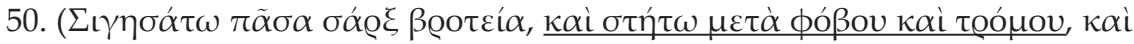

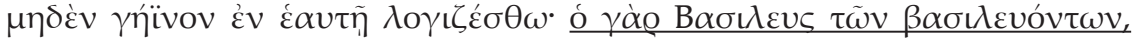

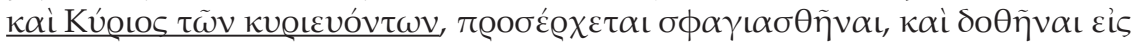

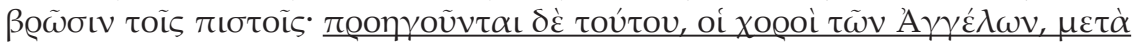

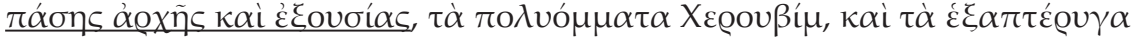

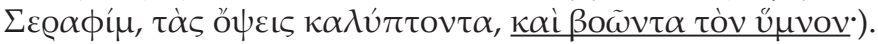

(14) Богослужебный сборник XVI в. (РНБ, Кирилло-Белозерское собр.,

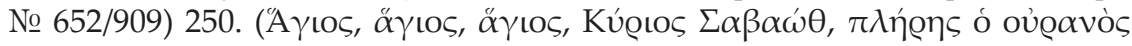

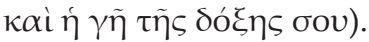


In a relatively small fragment of his work Epiphanius interweaves two different excerpts from the Divine service texts, uniting them with each other and mixing them with the author's words. Both quotations are taken from hymns that compose the core of the liturgy. Moreover, an allusion arises to one of the most important services in the yearthe liturgy for the Great Saturday. It is well known that the service of the Great Saturday precedes the paschal night and symbolically represents the Descent of Christ into Hades and the Resurrection. The medieval reader must have felt the feelings of the hero, who into one short phrase has introduced excerpts from the main texts of the central Orthodox Divine service, and the condition of the author, who could not express his feelings in any other way.

Let us bring in several fragments from the Life of Stephen that are bound up with the Triodion cycle. Thus Stephen, while exhorting the inhabitants of Perm, cites a quotation from Deuteronomy that is at the same time a verse from anheirmos from the Great Lent. Let us compare these texts: the everyday, the Biblical and the Divine service. Epiphanius writes: «Монсий во Втором закон' глаголя: Вонми, неБо, и възгАагою, үсАыши, земАе, гАаголы үстъъ монх [...]» [ЖСП 1995: 200]. "Moses says in Deuteronomy: Attend, O heaven, and I will speak, hear, O earth, the words of my mouth" [...] (LSP 1995: 200). In Deuterопоту it says: «Вонмн, нево, и възглаголю, услышн, земле, глаголы устъ монх" [Втор. 32:1]. "Attend, O heaven, and I will speak, hear, $\mathrm{O}$ earth, the words of my mouth" (Deuteronomy 32:1). In the heirmos of the second ode of the canon which is heard only during the Great Lent, and is left out on other days of the year, there are these words: «Вонми, нево, и возглаголю, и воспою Хрнста [...]» [Ирмодог XIV в.: 1. 4, об.]. "Attend, $\mathrm{O}$ heaven, and I will speak, and I shall sing of Christ [...]" (Heirmologion XIV c.: f. $4 \mathrm{v}) .{ }^{15}$

If the general quantity of quotations taken from the Triodion cycle in the Life were not so great, we could suppose that in the given case there was only a reference to Holy Scripture before us. But the medieval reader, being well acquainted with the Divine services, could not, having once caught the feelings of the author, fail to draw parallels between the Life of Stephen and the hymnography of the Great Fast and Pascha. Moreover, the author, as a rule, sets out the Divine service fragments in

(15) Ирмолог 14 в. (РГБ, собр. Тр.-Серг. Лавры, ф. 304/I, № 19) л. 4 об.

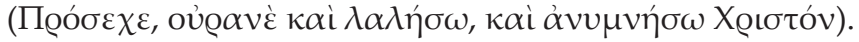


the text next to each other, which helps in the creation of a sufficiently sharp image of the Divine services of the Great Lent and Pascha.

The excerpts from the festal services of Pascha and the seven weeks after Pascha are more often used by the author in the chapter $«$ прнзванни и о върованньн многих языкъ" ("On the Calling and on the Believing of many Nations"). The first half of this chapter consists of various praises of God, Who blessed the enlightenment of the people of Perm. All the praises represent verses from the Psalms, which Prokhorov noticed in his publication of the text of the Life [LSP 1995]. However, what we have is not simply a quotation from the Psalter, but a selection of those psalm verses that are used in the festal liturgies. The majority of the quotations made by Epiphanius are taken from the Paschal service. A smaller number, the minority are from the service of the Ascension (a feast that is also a part of the Triodion cycle). One quotation refers to the already cited service for the Great Saturday, the second one - to the Nativity of Christ, which is not linked at all with the Triodion, but enters harmoniously into the general festal context of the given chapter of the Life. Moreover, we also find here one quotation from a weekday antiphon which, like the Nativity verse, in its meaning and style does not contradict the general mood created by the author in this fragment of the text. The whole chapter is penetrated with paschal feeling, so that the very event of the conversion of the people of Perm to Orthodoxy is represented as forefiguring their future resurrection, which became possible because Christ is risen. This mutual interconnection between the Gospel and the time of Epiphanius is often emphasized by the author of the Life with the aid of his use of hymnographical texts in the context of a literary source. We saw such a link in the chapter «Молитва за Церковь» ("Prayer for the Church"), where the hagiographer uses heirmoses that serve as original ties in the genre of the canon linking the church service with Biblical history. But in the chapter on the calling of the peoples such stylistic ties drawing the attention of the reader to the Gospel events became quotation from the festal services.

As in the case of the use of heirmoses, Epiphanius in the present chapter resorts to quotations and maintains a strict regularity: he chooses those psalms which are heard at the very beginning of the liturgy and in are called "festal antiphons" in the service. The antiphons are chanted as a rule alternately by two kliroses, so that each verse is heard twice. This naturally helps their memorization and the ability of readers of Epiphanius' Life to catch these parallels. Thus Epipha- 
nius writes: «И пророкъ Давыд рече: Хвалнте Господа всн языци, вси языци восплещете рүккамн [...]» ("And the Prophet David says: Praise Christ the Lord, all ye nations, clap your hands, all ye nations $\left.[\ldots]^{\prime \prime}\right) \cdot{ }^{16}$ Let us compare this with one verse from an antiphon for the Ascension: «Всн языци восплещете рукамн, восклнкнете Богу гАасом радованїя» ("All ye nations, clap your hands, cry out to God with a voice of rejoicing"). ${ }^{17}$

A line lower, the hagiographer cites these words: «Усмышите, всн языци, внгшнте, всн жнвущни по вселен'й, земнни же сынове

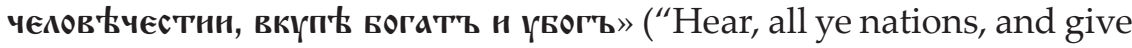
heed, all ye that live in the world, those born of earth and the sons of men, rich and poor men together"). ${ }^{18}$ Again we have nothing else than the verses from the antiphon for the Ascension, only in the given case Epiphanius joins together two verses which in the Divine service are separated from each other by one short prayer: «Услышнте сия вси языци, внүшите, всн живүщен по вселенн'й земнин же сынове челов'честин, вкүп' вогатъ и увог"ъ» ("Hear this all ye nations, give heed, all yet that live in the world [here a short hymn of the Ascension, that is, the troparion, is inserted $-S$. Sh.], both ye that are born of earth and the sons of men, rich and poor men together" $).{ }^{19}$ Further on Epiphanius writes: "Воспойте Господеви вся земля, воскликни Богу вся земля, вся земля да поклонит Ти ся и да поет Тевь, да поет же имени Твоему, Вышний» ("Sing to the Lord, all the earth, shout to God, all the earth, let all the earth worship Thee, and let it chant unto Thee, let it chant unto Thy name, O Most High"). ${ }^{20}$ In the given case Epiphanius again quotes two verses in a row which in the antiphon are separated by the paschal troparion and by two other verses. Thus in the Divine service we read the following: «Воскликните Господеви вся земля [...] Вся земля да поклоннтся Тев' и поет ТевЊ, да поет же имени Твоему, Вышний» ("Cry out to the Lord, all the earth [here two verses also taken from the Psalter, and the troparion of Pascha, are

(16) Прохоров, Святитель Стефан Периский..., 170.

(17) Триодь цзветная 16 в. (РГБ, собр. Тр.-Серг. Лавры, ф. 304/I, № 399)

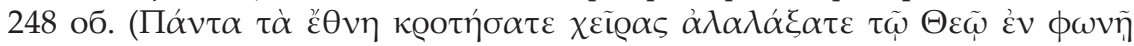

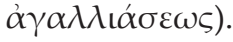

(18) Прохоров, Святитель Стефан Периский..., 170.

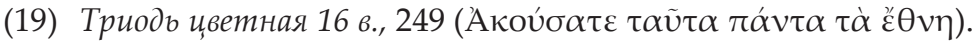

(20) Прохоров, Святитель Стефан Пермский..., 172. 
inserted - S. Sh.]. Let the whole earth worship Thee and chant unto Thee, let it chant unto thy name, O Most High"). ${ }^{21}$

This comparison of the chapter of the Life under investigation with various festal antiphons could be continued, because practically half the chapter consists of various antiphonal verses.

Moreover, we find interspersed in the given fragment of the Life several hymnographical texts that are also taken from the beginning of the liturgy, but not included in the antiphons. Here Epiphanius turns to the prokeimena - short chants consisting, as a rule, of one or two verses from the Psalter and performed before the reading of the apostolic epistle at the liturgy. The order of performance of the prokeimena presupposes their repetition three times during the Divine service and an especially extended and flowery chant. Again, this is a case when Epiphanius quotes the most memorable and recognizable liturgical texts. Thus the hagiographer writes: «Въскресни, Божє,

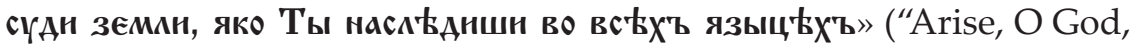
judge the earth, for Thou shalt have an inheritance among all the nations"). ${ }^{22}$ This is a word-for-word quotation of the prokeimenon from the liturgy for Great Saturday: «Въскреснн, Боже, сүан земмн, яко

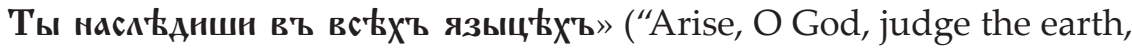
for Thou shalt have an inheritance among all the nations"). ${ }^{23}$ Another time, the hagiographer resorts to the prokeimenon for the Ascension. In the Life, several lines before the quotation of the paschal prokeimenon, we read: «Њъзнеснся на небеса, Боже, и по всей земли слава Твоа" ("Ascend into the heavens, O God, and Thy glory is over all the earth"). ${ }^{24}$ Once again we have here a word-for-word quotation of the Ascension prokeimenon: «Вознесеся на некеса, Боже, по всей земин слава Твоя» ("Thou hast ascended into the heavens, O God, and Thy glory is over all the earth"). ${ }^{25}$ Later in the text of the chapter under analysis we meet several more excerpts from the paschal service and, perhaps, by virtue of an exception, one reminiscence from the Nativ-

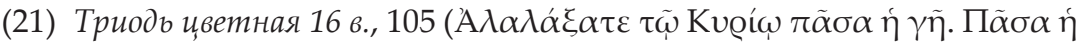

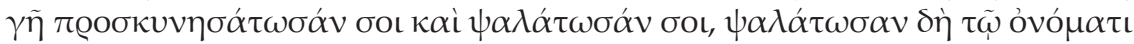

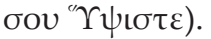

(22) Прохоров, Святитель Стефан Пермский..., 172.

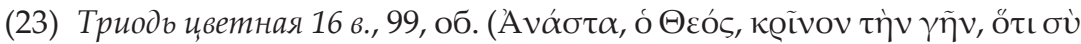

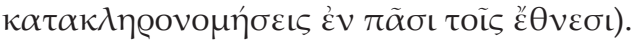

(24) Прохоров, Святитель Стефан Пермский..., 172.

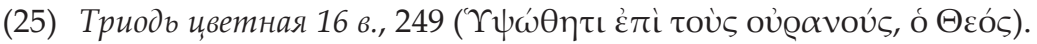


ity service. In other chapters of the Life we can discover quotations from the services of the Great Fast which also form part of the Triodion cycle.

Also related to the same cycle is a series of quotations from the Vespers and Compline, to which Epiphanius resorted in the text of the Life of Stephen of Perm. Thus the hagiographer more than once uses a phrase from the Vespers of the Great Fast with hardly any changes: "Вам во дана Бысть Благодать молнтнся за ны» ("Tо уоu [bishops] was given the grace to pray for us"; ${ }^{26}$ "Тев' Бо дана Бысть Бмагодать молнтнся за ны» ("To thee [Stephen] was given the grace to pray for us"). ${ }^{27}$ In Vespers this is addressed to John the Baptists and sounds as follows (the similar phrase is underlined): «Крестнтелю Хрнстовъ, всеХъ насъ помянн, Аа нзБавнмся отъ Беззаконнй нашнХъ, ТевЊ Бо дадеся Благодать молнтнся за ны» ("O Baptist of Christ, remember us all, that we may be delivered from our iniquities, for thou hast been given grace to pray for us). ${ }^{28}$ Here Epiphanius, first of all, underlines the link between the exploit of Stephen and the mission of John the Baptist, and secondly, once more directs the reader to the Triodion cycle. To it can also be referred the excerpts from Great Compline which are often found in the Life. For example: «[...] рци к ним: Разумейте, языцы, и покоряйтеся!» [ЖСП 1996: 76] (“[...] Say to them: Understand, ye nations, and submit yourselves!" (LSP 1996: 76)). In Great Compline this verse from the Psalter begins one of the triumphant places in the service and presupposes repeated chanting of a phrase used by Epiphanius: «Эъ намн Богъ, разумейте, языцы и покаряйтеся, яко с нами Бог"ъ» ("God is with us, understand, ye nations, and submit yourselves, for God is with us"). ${ }^{29}$

Great Compline is served on the eve of the great feasts of the Lord such as the Nativity and Theophany, and also every day in the first week of the Great Lent. As is known, in this week it is precisely Compline that becomes the distinctive centre of the Divine service insofar as it contains the canon by Andrew of Crete. This canon was a fa-

(26) Прохоров, Святитель Стефан Пермский..., 74.

(27) Ibid., 242.

(28) Псалтирь с возследованием 15 в. (РГБ, собр. Тр.-Серг. Павры,

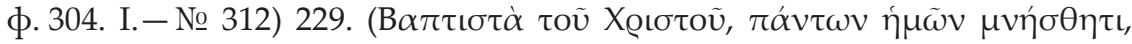

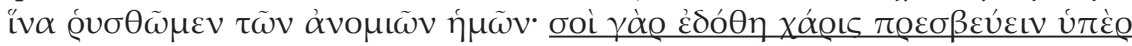
$\underline{\eta} \mu \tilde{\omega} v)$.

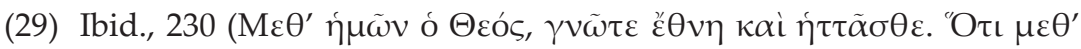

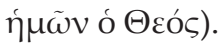


vourite hymnographic work in Medieval Rus'. Its reading drew into the church great numbers of people, and so it itself, together with the Compline that contained it, was well known to a wide circle of listeners. The phrases taken from Compline must inevitably have been perceived by the medieval reader of the Life as allusions to the first week of the Great Lent, that is, once more, to the Triodion cycle. This perception was strengthened still more by the abundance of quotations from other services in the Triodion used by Epiphanius. Therefore, in quoting from Great Compline, Epiphanius undoubtedly counted on definite associations that could have been elicited among readers of the Life of Stephen.

But what was it about the Triodion cycle that attracted Epiphanius? In the Life we meet at least two discussions touching on this period in the yearly cycle of Divine services. First, the hagiographer pays special attention to the month of March, which, from his point of view, was symbolically linked with the beginning of the enlightenment of the people of Perm. When relating how the first church built in Perm was consecrated by Stephen in the name of the Annunciation of the AllHoly Mother of God (a feast that takes place during either the Great Lent or Bright Week), Epiphanius takes time out from his narrative to think about the significance of this choice and the time of the celebration of the feast of the Annunciation. He links the baptism of the people of Perm with the month of March and, at the same time, with the events of the coming of Christ and His resurrection. All these events, as Epiphanius says, are preceded and initiated by the Annunciation:

«Марта же месяца паки изранаьтяномъ ПасХУ праздноватн по вся льта үАержася выватн. Марта же месяца и БАаговещение высть Өвятыя Богороднца, еже арХангел Гаврнл влагов'сти Єй, егаа ЭЫн Божнй за наше спасенне с невеси сннде и вселнся въ пречнстүю үтрову Всесвятыя Вмадычнца нашея Богороднца и Прнснодевыа Марна и вез съмени плоть от нея въспрннм. Марта же месяца и распятье Хрнстос волею претерп' и смерть 3 а ны пострада, и воскресенне вогольпно нам праздновати уставн. Марта же месяца паки чаем воскресенья мертвым и втораго Прншествня Хрнстова [...]. Аа якоже Благовещенне началный Есть Празаннк Празннкомъ, и сПасенью нашему НачатоК и в'Ъчн'לй тайн' явленье, Такоже и церкви пермьския - начаток спасенью Пермьския земли и вьрь Хрнстов' явленье» ("Again it was decreed that the Israelites should celebrate Pascha in the month of March in every year. And the Annunciation of the Holy Mother of God, which the Archangel Gabriel announced to her and when 
the Son of God came down from the heavens for our salvation and took up His abode in the all-pure womb of our All-Holy Lady and Mother of God and Ever-Virgin Mary, and without see took flesh from her, was in the month of March. And the crucifixion of Christ, when He voluntarily suffered death for us, together with the resurrection are decreed to be celebrated by us in the month of March. And again we wait for the resurrection of the dead and the second Coming of Christ in the month of March [...] And just as the Annunciation is the feast that begins the feasts, and the beginning of our salvation and the revelation of the mystery that is from eternity, so the Church in Perm was the beginning of the salvation of the land of Perm and the revelation of the faith of Christ"). ${ }^{30}$

The second of Epiphanius' discussions in his chronicle deals with the time of the death of Stephen. It is also linked with the Triodion cycle: the holy hierarch died in April in the second week after Pascha. If we take into account the fact that in Rus' the reading of the Lives of the saints during the Divine services or in the cell was usually bound up with the celebration of the memory of the saint, then all the Great Lent and Paschal motifs introduced into the text by Epiphanius must have been perceived with great vividness by the medieval readers: the memory of the holy hierarch Stephen always comes in the first weeks after Pascha. During this time they must have had vivid memories of the Great Lent and the feast of the Resurrection of Christ.

In introducing fragments from the Divine service into the Life, Epiphanius was evidently also taking into account the musical aspect of hymnography. We have already spoken about Epiphanius' possible musical talent: on the Sticherarion rewritten by his hand from the collection in the Holy Trinity - St. Sergius lavra chant notations have been discovered whose authorship has hypothetically been ascribed to Epiphanius the Wise. The researcher S. V. Frolov has made several remarks with regard to the musical character of this chant which are also not without interest for a characterization of the hagiographer's writing style. Having changed the more ancient chant when rewriting the Sticherarion, the scribe - in all probability, Epiphanius - introduced certain innovations into the composition of the verse. "The chanter," writes Frolov, "seems to have used every opportunity to realization this arrangement, which would have responded to the main demands of the verse-prayer. First of all, there is the syntactical parallelism [...] But here we can also talk about rhythm [...], and the equal number

(30) Прохоров, Святитель Стефан Пермский..., 92-94. 
of syllables, that is, syllablism $[\ldots]^{\prime \prime} \cdot{ }^{31}$ The researcher notes a series of devices used by the chanter: the division of the composition into three parts, the attention to this arrangement, which in part compensates for the absence of anaphorical repeats, the smoothing out of lines in accordance with the same number of syllables, which, according to V. V. Kolesov, corresponds to the number of syllables in the Old Slavonic epic verse. This points to the author's increased attention to " $[\ldots]$ the putting in order of the musical-textual line and verse nature of this work" ${ }^{32}$ It is also worth noting on what words the chanter placed fity (Russian plural of fita), that is, where there was the most extended chanting of a single syllable, indicated in Old Slavonic singing by the letter $\theta$ (fita). The author of the given work places fity over the words «Бог"ъ», «вмасть», «ммү [Богу]» and «пов'дати» ("God", "power", "to Him [God]" and "to tell"), supposing thereby to hold the attention of his listeners on these moments in the verse. The most important fragments of the text have been marked out. Frolov, when discussing the placing of fity, speaks in the given instance of a kind of musical amplification. ${ }^{33}$

The phenomenon of syncretism in Old Russian art allows us to speak of parallel artistic principles in the literature and musical culture of the Middle Ages, and with the help of these parallels allows us to bring out the definite hidden meanings of various literary methods. Thus the appearance of the term "amplification" to signify both literary and musical particularities of the works of Ancient Rus' is not accidental. In the system of chanting amplifications are encountered in the form of fity, and this corresponds to a certain degree to the stringing out of epithets, metaphors or synonymous combinations in the hagiography of the era of the second South Slav influence. In characterizing the phenomenon with that degree of approximation that is possible within the bounds of the present investigation, we shall point out that fity in the ancient art of chanting indicated a definite, quite drawn-out melody that corresponded to the minimum number of syllables in the text - most often, one syllable. That is, a drawn-out chant with fity was pulled out of the text, and the melody existed for some time in separation from the words. At the moment of fity chanting, the content

(31) С. В. Фролов, Новые аспекты изучения Стихираря 1380 г. Собр. Троице-Сергиевой лавры, № 22, ТОДРЯ 50 (1997) 200-201.

(32) Ibid., 201.

(33) Ibid., 203. 
of the hymnographical work retired into the background, while the ornateness of the Divine service melody occupied centre stage. This elicited a certain dying down of the listerner. But this is the same dying down, contemplation and meditation that we discussed in relation to the "rejoices" in the akathistos and the "interweaving of words". The separation of the melody from the text is not emptiness of meaning, but the drawing out of the hidden meaning of sub-text, it is time for immersion in the Jesus Prayer. Not accidentally did the flourishing of ornate Divine service chanting on Athos coincided with the time of the spreading of the teaching of hesychasm on the Holy Mountain, together with the creativity of Serbian scribes who consistently reflected the teaching on "mental activity" in their compositions. Chanting is closely linked with prayer, although it includes no teaching on it. In a similar way the hagiography of Epiphanius, in contrast with the whole of the literature on the lives of the saints contemporary with him, contains no teaching on unceasing prayer and deification, but at the level of style reflects the condition of the praying soul and the contemplative mood of the author. In this Epiphanius is close to the melodists of his time, who composed ornate chants for long services. When discussing the significance of chanting in the Divine services and the aid it gives to prayer, the Old Russian chanters referred to the sermons of John Chrysostom, which could clarify certain general principles of the world-view of medieval man: "The Lord joined melody with prophecy in order that everyone, being attracted by the smooth flow of the verses, should proclaim the sacred chants with perfect ardour. Nothing so excites the spirit and gives it wings, nothing so drags it away from the earth and bodily ties, nothing so fills it with love for wisdom and indifference to worldly affairs as harmonious, sacred chanting put together according to the laws of rhythm".$^{34}$ Love for wisdom and indifference to worldly affairs, the renunciation of the earth and bodily ties - that is what the ancient hymnographers strove for, and that is the means for the attainment of attentive prayer. It is evident that Epiphanius, too, had this aim in mind when he submitted certain fragments of the Life to rhythm, binding together synonymous enumerations with assonances, alliterations, homeoteleuta, paronymous words, and anaphorisms. His works are distinguished by this calm sonority and lyricism,

(34) В. М. МетАллов, Очерк истории православного цеерковного пения в России (Москва, 1896) 35. 
which is not characteristic even of his closest follower, Pachomius the Logothete.

And so the hymngraphical quotations and reminiscences that we often encounter in Epiphanius' hagiography give a certain musicality to the whole work. Our attention is also drawn by the fact that, as a rule, the author observes a definite regularity in his choice of hymnographical sources. If any chant from the Divine services consists of two indivisibly linked parts - text and melody, - then each of them, heard or read individually, is linked by the recipient with its second part by association. Thus the text of this or that chant, which has been heard many times by the medieval man in church, is always linked in the man's perception with a definite melody. And, when we penetrated into Epiphanius' Lives, the hymnographical quotations elicit musical associations in his readers. The quotations from the heirmoses bring to mind those melodies to which theheirmoses are chanted. A chapter of the Life, constructed out of antiphon verses, is subconsciously linked by the reader with the triumphant antiphon chant. When quoting heirmoses, the author of the Life as a rule puts two heirmoses relating to one tone or chant next to each other. The medieval reader, catching one of the quotations, begins mentally to chant a definite melody, and, on coming to the second quotation, continues the same chant. But then the combination of quotations leads to a definite combination of chants, and a musical sub-text appears behind the text of the Life. In this way Epiphanius creates an original musical mosaic in his work. Let us cite once more the fragment form the chapter "Prayer for the Church" from the Life of Stephen, indicating in brackets the tones to which theheirmoses used by Epiphaius were chanted:

«[...] Иже словом в начатц' үТтержий невеса, разумом(8) и невесного круга врьхъ створь (8), ИЖе наА водамн неБо уТтержнй, второе Же үТтвежнй нн на чем Же земАю повел'Ннем Яи и распространнв неодрЪЖНмую земную тяготу, юЖЕ на Тверди ея основавый наА водамн многамы, яко и на водаХ пов'ССв юо неОАръжнмо (5); съдТтекная сүщн и съдръжащна вся(1) Божня

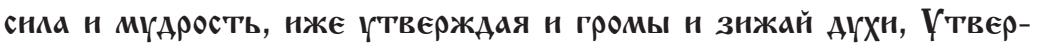
женне сый твердое, и недвнжимое Речение, и УТтерженье на Тя над њющнмся(3), и Ты еси Утверженье прнтькающнм Ти,

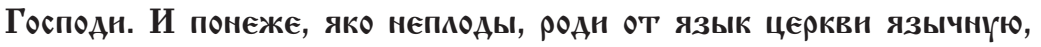
неПлодящүю церковь (2) Эвою үТтеран, Хрнсте, южЕ стяжа снАою Креста Твоего [...], юже стяжа честною Яи кровню(8), юже үтТверан, Господн, на камени твердТмъ, на каменн недвнжнм'М, на камени вЊры на камени запов'дей Твонх(8), на камени ис- 
пов'Вання Твоего, на каменн церковн'Мм [...]» [ЖСП 1995: 236]. "[...] Who hast in the beginning established the heavens by Thine understanding (8) and built the vault of heavens (8)..., Who has established the heaven upon the waters, and hast again established the earth upon nothing by Thy command and hast hung it while its weight ungovernably drags it down, founding it firmly upon many waters, as Thou hast hung it ungovernably upon the waters (5); O Power and Wisdom of God, the Creator and Sustainer of all (1), Who hast established the thunders and the winds, being the firm Establishment and Immovable Word, and the firm Foundation of all that hope in Thee (3), and Thou art the Foundation of all that flee to Thee, O Lord. And do Thou establish, O Christ, the infertile Church of the Gentiles (2), which Thou hast acquired by the power of Thy Cross [...], which Thou hast acquired by Thine honourable blood (8), which do Thou establish, O Lord, on the firm rock, on the immovable rock, on the rock of faith, on the rock of Thy commandments (8), on the rock of Thy confession, on the rock of the Church" (LSP 1995: 236).

Epiphanius uses heirmoses of tones 1, 2, 3, 5 and 8. Most often we have the eighth tone, whose melodic contour evidently, from the point of view of the author, most answered to the feeling conveyed in this chapter. But, as is well known, the fifth and first tones were closely linked with each other in the system of medieval Russian chanting, and they developed one and the same musical theme. And only the second tone appears in this fragment once, as the culmination: probably it was called to emphasize the thought that the Coming of Christ had brought the unbelieving Gentiles into the true Church. It is precisely about them that the Life "sings" in the second tone. But then again there comes the eighth tone, as if to assure us that the Church of the Gentiles who received Christianity has entered harmoniously into the bosom of the true Church, just as the second tone interweaves harmoniously with the eighth tone in the text.

An original melodic shape is also inherent in the chapter reviewed earlier by us on the bringing of many peoples to the faith: the chapter begins with antiphonal verses, and then two festal prokeimena are put in one after the other. At the melodic level they sounded different from the antiphons, and in this way they can serve as something like a musical completion of the antiphonal melodies in the subtext of this chapter.

The akathistos compositions which Epiphanius includes into his works must have elicited in the memory of his medieval readers vari- 
ous antiphonal chants. It is natural that this perception of this work should have slowed down its reading still more, but it was precisely this slowing down that was valuable for the hesychast author. As has already been said, akathistos compositions and amplifications of various kinds are related to medieval fity chanting, which slows down the chanting of the hymn and immerses the listener into the contemplative-meditative condition characteristic of the doer of "unceasing prayer". Slowing down is important in itself for the man of prayer; in its relative abstraction from the text, the subtext of this stopping of the narrative is important. But the stopping is attained through the inclusion into the melody of the fity, and into the literary work - of lyrical ecstasy, the stringing together of quotations or synonyms.

The paradox between "hesychia" and grandiloquence, which we note in the literary work of the hesychasts, also finds its incarnation in the similarity between fity chanting and hagiographical amplification: one and the same aim is attained in the music of the Divine services through the absence of words and the chanting of fity, while in literature it is attained through the compression of metaphors, epithets or quotations. In his works Epiphanius the Wise reflects more consistently the striving of the Old Russian word to merge with the melody. He attains this with the aid of the introduction into the text of assonances, alliterations, anaphorisms, homeoteleuta and words deriving from a single root, with the aid of turning hagiographical time into Divine service time, and also through the skilful choice of hymnographical quotations and the scattering within the Life of akathistos structures which help to produce a special slow rhythm in the narrative. Prayer and silence, being the fundamental components of the practice of "mental work", are for Epiphanius original styleforming factors: they represent both the conditions of his work, and its aim.

And so the link with the paschal cycle of Divine services in the Life of Stephen of Perm is conveyed by Epiphanius on the level of stylistics with the help of the introduction of quotations and reminiscences, and also with the help of the creation of a musical subtext in the work. In a similar way Epiphanius conveys the link between the conversion of the people of Perm to Biblical history when he introduces fragments of heirmoses into the Life. The centre of the writer's attention in both cases is prayer, to which he calls the reader, interweaving prayer texts into the Life and creating a correspondence between his work and the yearly cycle of Divine services and its critical moment - the feast of 
Pascha. In the Life of Sergius of Radonezh by Epiphanius cell prayer is often mentioned, but in the Life of Stephen - church prayer. But both works, judging from their volume and unhurried narrative rhythm, are aimed at cell reading. Being created in the quiet cell of the hesychast, they require a corresponding atmosphere for reading: secluded, free from vanities ad cares and, most important, prayerful. On the level of content Epiphanius does not introduce into the Life any teaching on the necessity of "unceasing prayer" or constant standing before God, but on the level of stylistics the hagiographer so skilfully conveys the condition of the praying soul that it touches the reader and stirs him, against his will, to seclusion and prayer. In Epiphanius' hagiography a quiet intonation bound up with a prayerful striving for heaven is the stylistic dominant, while the creation of a prayerful atmosphere within the work, that "hesychia" of which the great ascetics of antiquity spoke, is the main stylistic task of the hagiographer. All the artistic means used by the author are necessary for him insofar as they correspond to this task and his ideas about the Beauty from on high and deification.

In the article author explores system of divine service quotations in the Life of Stephen of Perm, written by Epiphanius the Wise. The author argues that the quotations from religious texts are arranged in the Life of a coherent system associated with one year prayer circle, particularly the Triodion cycle. Exploring of this system allows us to see new meanings in the Life, and have another look at the chronology of described events in the Life.

\section{SUMMARY}

The author argues that the quotations from liturgical texts in the Life of Stephen of Perm are arranged as a coherent system associated with the yearly liturgical circle, and especially its Triodion part. This fact is interesting not only for better understanding of the text but also for establishing of the chronology of some episodes. 